\title{
Prof. Hans du Plessis
}

Departement Afrikaans-Nederlands

\section{IETS OOR SPREKERSEMPATIE: 'N FUNKSIONELE BESKOUING}

\section{INLEIDING}

Empatie, sê Kuno (1975:49), kan beskryf word as: "the speakers's identification, in various degrces, with the referent of a participant in an event". As 'n mens dié stelling as waar sou aanvaar, kan die term empatie uitgebrei word sodat dit ook die volgende insluit: empatie kan beskryf word as die spreker se identifikasie met die referent van 'n objek in 'n sin waarin die spreker die onbekende lakaliteit van 'n objek beskryf in terme van dic lokaliteit van 'n ander objek. Verder kan 'n spreker, as hy $\sin$ (1.1c) hicronder uiter, sy houding t.o.v. die hoorder uitspreck.

As antwoord op 'n vraag soos (1.1a), kan die onbekende posisie van die bevraagde objck beskryf word, in terme van die posisie van 'n ander objek in dieselfde sin, mits die posisie van lg. bekend is aan sowel spreker as hoorder.

1.1 a waar is die asıak?

1.1b die asbak is op die tafel

Normaalweg sal die volgende sin onaanvaarbaar wees:

1.1c dic tafel is onder die asbak

Ons wil cgter daarop wys dat (1.lc) onaanvaarbaar is, tensy dic spreker wat dié betrokke sin sê, eintlik sy houding t.o.v. ôf ren van die objekte of t.o.v. die hoorder probeer uitdruk. M.a.w. as die spreker met dic sin nic daarop uit is om die tafel te lokaliseer in terme van die lokaliteit van die asbak nie. Ons wil probeer aantoon dat die onaanvaarbaarheid van (1.Ic) toc te skry $[$ is aan dic oortreding van 'n funksionele beperking en nic van 'n suiwer sintaktiese beperking nie.

\section{DIE KONSTRUKSIE}

Ten einde 'n soort geformalisecrde beskrywing van dic konst ruksie in (1.1b) te gee, kan 'n mens die onderhawige konstruksie só stel: 'n spreker kan die. lokaliteit van 'n objek $(\Lambda)$ beskryf aan ' $n$ hoorder, met verwysing na die lokaliteit van 'n ander objek (B). Sodanige konstruksic kan dir volgende sintaktiesc vorm hê: 


$$
\left.2.1 /\left[\Gamma_{\mathrm{NS}} \wedge \mid \text { WeES } \quad\left(\mathrm{Vsgr}_{\mathrm{NS}}^{\mathrm{Vs}} \mathrm{I}_{\mathrm{N}} \mathrm{B}\right]\right)\right\}
$$

In dić konstruksic word onbekende of nuwe inligting aan die hoorder verskaf in terme van bekende of ou inligting. Die hoorder ken nie die lokaliteit van objek A nic. Hirrdic onbekende lokaliteit word dan aan die hoorder beskryf m.b.t. die bekende lokaliteit van objek B. Die lokaliteit van B is of bekend aan sowcl spreker as hoorder ò dit is maklik waarneembaar deur albei gespreksgenote. M.a.w. waar A se posisie net aan die spreker bekend is, is B s'n aan albei bekend of deur albei maklik waar te neem. Daarom word $A$ gelokaliseer d.m.v. 'n sintaktiese verwysing na B, bv.

2.2 die bock is op dic lessenaar

2.3 jou skoene is op die vloer

2.4 die telefoon is in die hoek

2.5 die blomme is op die klavier

2.6 dic ontut is agter die deur

2.7 Gouclokkics is op die bed

Werkwoorde soos slaan, lé, loop, sit, ens. kan ook in dié soort konstruksie gebruik word, maar ons gee nic daaraan aandag nie. Vergelyk bv.
2.8 dic asbak staan op die tafel
2.9 dic hocd lê op die bank
2.10 die pad loop oor die bult
2.11 dic koppies sit op die rak

Ons ignoreer dus die verskil wat ons intuitief aanvoel in dic betekenis van die volgendc:

2.12 Reagan sit nou in die Withuis

2.13 Reagan is nou in die Withuis

Om terug te kecr tot die sinne (2.2)-(2.7): die omkering van die NS'e in die sinne is nie altyd moontlik nie:

$2.2 a$ dic Iessenaar is onder die boek

Vergelyk ook 'n soortgelyke omkering in die ander sinne.

Hierdie "onomkecrbaarheid" moet op cen of ander wyse dus voorspel kan word. 'n Metasintaktiese beperking lyk vir ons na 'n ellelange omslagtighcid en daarom wil ons vervolgens betong dat dic onaanvaarbaarheid te voorspel 
is indien die inligtingstruktuur van die sin as beperkingsbasis dien. Die onaanvaarbaarheid van sodanige omkering is daarom te wyte aan die oortreding van 'n funksionele beperking wat ons die Waarneembaarheidsbeperking sal noem.

\section{DIE WAARNEEMBAARHEIDSBEPERKING}

Ofskoon ' $n$ sin soos (2.2a) nie streng gesproke ongrammaties is nie, is dit tog onder bepaalde omstandighede onaanvaarbaar. Omdat dit nie ongrammaties is in die gewone sin van die woord nie, is dit tog onaanvaarbaar en om hierdie rede is dit moeilik metasintakties beperkbaar. 'n Sintaktiese beperking gaan in elk geval veels te sterk wees, want dit sal ook die volgende sinne as ongrammaties moet beperk as die beperking suiwer gaan om die volgorde-verskuiwing van die objekte binne die onderhawige konstruksie.

3.1a die huis is langs die groot boom

b die groot boom is langs die huis

3.2a die kombers is oor die lyk

b die lyk is onder die kombers

3.3a die koppie is op die piering

b die piering is onder die koppie

Nòg die (a)- nòg die (b)-sinne hierbo is egter ongrammaties of onaanvaarbaar.

Die omkering van bostaande (a)-sinne in die (b)-sinne is egter nie moontlik in die geval van die oorspronklike voorbeeldsin, (1.lb) in (1.1c) nie:

1.1b die asbak is op die tafel

1.1 die tafel is onder die asbak

Dit wil voorkom of daar geen konstante sintaktiese faktor is wat die omkering sou kon beperk nie.

Teen hierdie agtergrond lyk dit dan gangbaar om 'n beperking te plaas op die sinsperspektiewe binne die sin. Daarom kan 'n funksioncle beperking soos die volgende gepostuleer word:

\subsection{Die waarneembaarheldabeperking (WB)}

Geen objek waarvan die lokaliteit onbekend is, kan gelokaliseer word met verwysing na die lokaliteit van 'n objek wat (a) bekend is of maklik waarncembaar is deur sowel spreker as hoorder, maar wat (b) minder 
waarnccunbaar is as e.g. objek nie.

As objek $\Lambda$ dus gelokalisecr word met verwysing na die lokaliteit van objek $B$, moet objek $B$ inakliker waargeneem kan word as objek $A$.

Ter illustrasic: $\Lambda s$ iemand vra: "Waar is die tafel?" in 'n vertrek, sal die posisic van dic tafel (wat vir die vraer onbekend is) aan hom beskryf moet word deur' $n$ ander persoon in dieselfde vertrek met verwysing na die posisie van 'n objek wat makliker waar te neem is as die tafel. (Ons aanvaar natuurlik ter wille van die betoog dat die lokalisering d.m.v. die onderhawige konstruksic gedoen word, en nie deur enige deiktiese verwysing van 'n direkter aard nir.) In oorcenstemming met die WB sal die volgende sinne onaanvaarbaar wees:

3.5 die tafel is onder die asbak

3.6 "dic tafel is langs die lepel

3.7 "die tafel is agter die koppie

3.8 dic tafel is op dic skoen

Hierteenoor sal die volgende aanvaar word o.g.v. die groter waarneembaarheid van die objek $B$.

3.9 dic tafel is in die hoek

3.10 die tafel is langs die bank

3.11 dic tafel is by die deur

In die voorbecldsinne (3.1)-(3.3) is die objekte ewe waarneembaar en daarom is die (a)-sinne en die (b)-sinne ewe aanvaarbaar.

Op grond van die WB sal die volgende sin onaanvaarbaar wees:

\subsection{2 "dic dak is onder die bal}

Sodra ' $n$ mens cgter in 'n bepaalde situasie kan aantoon dat die bal inderdaad mecr waarnecmbaar is as die dak, moet (3.12) binne dié situasie volgens die WB wel aanvaarbaar wees.

Stel u bv. die volgende voor: twee outjies lê op die voctbalveld na 'n harde spel dryfinkies. Gescls-gesels lâ die twee op hulle mage met die rugbybal voor hulle op dic gras. Die een seuntjie (sê die spreker $\boldsymbol{\Lambda}$ ) sien sy huis se dak 'n endjie verder. 
"Ons huis is onder die bal," sê hy. Die ander seuntjie (die hoorder B) ken nie dir posisie van $\Lambda$ se huis nie, maar wel die posisie van die bal. Ofskoon $\Lambda$ normaalweg nie die hu is se posisie sal beskryf in terme van die posisie van dic minder waarneembare bal nic, kan hy dit wel binne voorgaande situasie doen, aangesien die bal vir die betrokke gespreksgenote meer waarnecmbaar is as dic huis.

Kyk bv. na dic volgende paar:

3.13a waar is dic berg waarvan jy praat?

b die berg is agter daardic blom

(b) is heeltemal ganghaar as die gesprek plaasvind voor' $n$ skildery met 'n reuse blom op die voorgrond.

Daar bestaan ook heelwat gevalle waar' $n$ sin tog aanvaarbaar is, terwyl dit die WB oortree en ook nic in dié klas val wat in die vooralgaande paragrawe bespreck is nie. Ons wil betoog dat daar tog gevalle is waar die WB met opset oortree word, ten cinde die spreker se empatic met 'n objek uit te druk.

Gestel 'n spreker uiter die volgende sin:

\subsection{4 my tafel is onder die boeke}

As (3.14) 'n ant woord is op die vraag "Waar op aarde is jou tafel?", en (3.14) word gebruik nie om dic lokaliteit van dic tafel uit te clruik nie, maar om dic spreker se houding uit te druk t.o.v. die deurmekaar tafel, sal (3.14) t.s.v. die WB aanvaarbaar wees.

In 'n sin soos (3.14) probeer die spreker dus nie lokaliseer nic, maar hy spreek sy empatie uit met een van die objekte binne die sin of met die hoorder.

As albei dic volgende sinne aanvaarbaar is, is daar 'n funksionele verskil tussen hulle:

3.15 die asbak is op dic tafel

3.16 die tafel is onder die asbak

As die spreker egter met (3.16) die tafel wil lokalisecr is dit i.t.v. die WB onaanvaarbaar. Sou die spreker egter deur middel van hierdie sin sy gevoel of houding t.o.v. of die tafel of die asbak of dic hoorder weergee, sal (3.16) nie dic WB oortree nie, maar as 'n totaal ander soort konstruksie beskou moct word. 


\section{EMPATIE}

In die Inleiding het ons empatie reeds beskryf as dic spreker se identifikasie met die referent van cen van die objekte in die sin of met die hoorder binne'n bepaalde diskoers. In 'n sin soos (4.1) hieronder kan daar in die lig van die vorige aftelings nie sprake wees van lokalisering nie.

\section{1 die tafel is onder die asbak tcenoor: \\ 4.2 dic asbak is op die tafel}

Ons wil daarop wys clat hierdie twee sinne verskil versover daar 'n verskil is in hulle funksioncle doclwit. In (4.2) word die asbak gelokaliseer i.t.v. die lokaliteit van die lafol. In (4.1) het die spreker'n totaal ander doel, nl. dat die spreker sy houding uitdruk t.o.v. tafel of die hoorder en is hy nie primêr besig met lokalisering nic.

Dit impliseer natuurlik dat (4.1) nie bloot 'n antwoord is op die vraag waar die tafel is nic. Sou dit 'n blote antwoord op so 'n vraag wees, was dit neutraal t.o.v. empatie, en sou dit i.t.v. die WB onaanvaarbaar wees. Ons is egter van mening dat die spreker in hierdie sin met die lafel empatiseer.

Sou (4.1) uitgespreck word deur, sê 'n vrou wat bekommerd is oor 'n waardevolle tafel, kan (4.1) aanvaarbaar wees. Stel u 'n man en sy vrou voor wat in hulle sitkamer sit. Die man rook 'n sigaret terwyl hy die aandkoerant lces. Langs hom staan sy vrou se geliefde antieke tafeltjie. Op die tafeltjie is daar 'n asbakkie, naar die man is so verdiep in sy leesstof dat hy die as ingedagte aftik, maar dic hele asbakkie mistik. Die vrou sien haar dierbare ou tafeltjie nog vanaand afbrand. Haar verbale reaksie kan wecs:

\section{3 haai, jong, die tafel is onder die asbak}

Sy beskryf nic die posisie van die tafel nie, maar identifiscer haar met 'n objek in die sin, nl. dic tafel; sy druk dus empatie uit. Insgelyks kan sy natuurlik ook haar misnocë met die ongeërgdc man uitdruk.

Kyk ook na die volgende sinne:

4.4 dic lessenaar is onder die papiere

4.5 die bed is onder Gouelokkies

4.6 die vlocr is onder jou skocne

Bloot as lokalisering sou bostaande sinne onaanvaarbaar wecs, maar (4.4- 
4.6) is nic suiwer grammaticse omsetting van dic volgende (b)-sinne nic.

4.4a dic papiere is op die lessenaar

4.5a Gouclokkies is op die bed

4.6a jou skocne is op dic vlocr

(4.4)-(4.6) druk cmpatic van dic spreker uit en nic lokaliteit nic.

I.et op die sprekersempatie wat in die volgende sinne t.o.v. die grammatiese onderwerp uitgedruk word:

4.7 Ou Salie is al weer voor dic spicël

4.8 die vet tante is op my toon

Dit gaan in hicrdic twee sinne bepaald nie orn lokalisering nic.

\section{SLOT}

In 'n sin soos (5.1) word die boek gelokalisecr met verwysing na die lokaliteit van dic meer waarnecmbare, die tafel. As dit primêr gaan om lokalisering is (5.2) onaanvaarbaar omdat die boek minder waarnecmbaar is as die tafel. (5.2) sal egter aanvaar word as die spreker daarmee sy houding t.o.v. die deurmekaar toest and op die tafel wil uitdruk of sy afkeer van die hoorder in die bepaalde diskoers. As (5.2) dus sprekersempatie uitdruk, sal dic sin aanvaarbaar wees.

5.1 die bock is op die tafel

5.2 die tafel is onder die boek

\section{BRONVERWYSING}

KUNO, S. (Red.) 1975. Harvard sludies in syntax and semantics. (Vol. 1). I larvard University, Dept. of Linguistics. 